\title{
TEACHER TALK IN TEACHING ENGLISH FOR YOUNG LEARNERS
}

\author{
Nur Najibah Sukmawati \\ Universitas Pamulang \\ nurnajibah.sw@gmail.com
}

\begin{abstract}
The trend of teaching English as a foreign language in preschool has been rocketing in Indonesia. Taken into account, teaching English to young learners is beyond a mere teaching of language. Teachers should focus on students' lifestage development more than their knowledge. Particularly in terms of language development, utterances which involve social and cognitive development suggest teachers to consequently manipulate their linguistic choices to suit students'linguistic capacity. Aiming at analyzing teacher talk in teaching English for young learners from the perspective of sociolinguistics analysis, this descriptive study employed a group of kindergarten students and two teachers from a favourite kindergarten school in Surakarta. The findings showed that the teachers performed (a) simple grammatical pattern of utterances; (b) slow delivery utterances; (c) clear articulations; (d) restricted vocabularies; and (e) clear pauses in every utterance which all implied the significance of adjusting teacher talk on the extent of linguistic choices in teaching English for young learners to approach the flawless interaction during instructional process. This suggests the significance of modifying speech to adjust children's language capacity for the sake of better communicativeness between teacher and students.
\end{abstract}

Keywords: children, interaction, linguistic choices

\begin{abstract}
Abstrak. Popularitas pengajaran Bahasa Inggris sebagai bahasa asing untuk anak-anak semakin meningkat di Indoesia. Praktiknya, pengajaran bahasa Inggris untuk anakanak bukan hanya tntang mengajar bahasa.guru harus memperhatikan perkembangan dan opertumbuhan siswa disamping perkembangan pengetahuan. Secara khusus, dalam hal pengembangan bahasa, ujaran pada anak-anak yang masih terbatas dan berciri khas membuat guru harus mempu untuk melakukan manipulasi pilihan-pilihan ujaran yang sesuai dengan perkembangan kemampuan siswa. Penelitian deskriptif ini bertujuan untuk menganalisis ujaran guru dalam mengajar bahasa Inggris untuk anakanak dari perspektif aalisis sosiolinguistik. Objek penelitian ini adalah sekelompok siswa taman kanak-anak dari salah satu sekolah favorit di Surakarta.penelitian ini menemukan bahwa dalam berkomunikasi dengan siswa, guru memberikan (a) pola kalimat sederhana, (b) memperlambat kecepatan ujaran, (c) artikulasi yang jelas, (d) membatasi produksi kosakata, dan (e) jeda yang sangat jelas antara satu ujaran dengan ujaran berikutnya. Hal ini dilakukan guru untuk memaksimalkan pemahaman siswa sehingga siswa lebih mudah mengikuti kegiatan belajar mengajar. Hal ini menunjukkan bahwa memodifikasi ujaran penting dilakukan agar terjadi komunikasi yang lebih baik antara guru dan siswa.
\end{abstract}

Kata Kunci: anak-anak,interaksi, dan pilihan kata 


\section{Introduction}

The rocketing trend in learning English causes the increasing demand of learning the language. This paradigm has embraced parents to prepare their children from the very young ages by choosing schools providing English as one of the subjects to learn. Whereas in non-native speaking (NNS) counties like Indonesia, English was a commodity of secondary school in the past (Fauziati, 2010) yet recent demographic trends have far-reaching popularity of early childhood education (Ong, 2009: 9) to expand English learning under the belief that the sooner children learn English, the easier they can master (Taylor and Taylor, 1990; snow, 1993; and Gawi, 2012).

However, activities for kindergarten English learners -preschool lesson themes and fun exercises for children- have become important aspects of foreign language teaching (Jasmine, 2013) which suggests different instructional strategy because (1) children who come from homes where another language is regularly used may find it harder to learn English (McLaughlin, Blanchard, and Osanai, 1995); and (2) children's capacity to understand lecture is different from adults' (Law, Rush, and Clegg, 2014). Accordingly, teaching English to young learners involved more than merely teaching the language to concern (Fauziati, 2010). This is significant for every teacher to concern with. Accordingly, extra effort is necessarily demanded to teach young learners English which perhaps is perceived as something totally new for them.

One of the points to concern with teaching English for young learners is teacher talk which indispensably plays significant role in organizing activities. It does not only determine the merit of lectures, but also guarantee the merit learners will learn (Yanfen \& Yuqin; 2010). Teacher-talk varies in many perspectives (Bolitho, 2006) but at the same point focus on teachers' modification of speech when addressing learners in the classroom (Chaudron, 2001). This suggests the significance of sociolinguistics on the extent of understanding age as a factor of linguistics choices for teachers in teachinglearning process. In short, teachers should comprehend the idea of social development in teaching. To young learners, their social development influences their acquisition. In learning English and other subjects, they need help from adults in learning (Cameron, 2002) which can be manifested through proper utterance because there are possibilities that children abandon their efforts to communicate (Ashworth and Wakefi 2004) the times they are not in to what teachers say. Hence, teachers play significant role in embodying proper communication to their young learners to make instructional process a fruitful activity.

On the other hand, Colley (2014) has different thought of perceiving teacher-talk by pinpointing issue whether reducing the amount teacher talk in the classroom is also important to do. She concerns with teacher talking time (TTT) that can benefit students in the form of teacher demonstrations, conveying meaning and telling anecdotes. Accordingly, Colley suggests all language teachers to avoid habit of talking too much in lessons by (1) repeating instructions; (2) saying much more than the students when receiving a contribution; (3) asking lengthy questions; (4) echoing what students have just said in answer to a question; and (5) summing up. This circumstance may drive teachers to bewildering context to the extent of suiting talks to their students. One of the ways to solve this confusing matter is to take into account the students' level of linguistic mastery. In short, teachers must see this phenomenon a big challenge which must be taken into account. They have to initiate, adapt, and adjust the way they teach to younglearners' characters. Accordingly, this paper aims at analyzing teacher talk especially in language that teachers use (linguistic choices) in teaching English for young learners from the perspective of sociolinguistics.

Young learners are those who are between 0 to 15 years old. Where and when they learn 
does not matter so long as they start learning, they are a learner (Piaget, 1972: 67). This study specifies kindergarten students who vary from 4 to 5 years old as the object. Some characteristics of children are (1) they love playing and learning things while playing; (2) they talk about "here" and "now" only and not capable yet of conditional context; (3) they like getting known of meaning by associating it with objects they see, and; (4) they have short span of focus or easily feel bored of monotonous or continuous activities to do. These four points challenge teachers to set up learning activities as acceptable as possible for young learners to maximize their learning quality. In terms of cognitive development, children experience quick development. $0-2$ years old children possess intelligence that takes the form of motor actions. Further, $3-7$ years old children are in the pre-operation intelligence period which is intuitive in nature. $8-11$ years old are those who have cognitive structure with concrete operational stage. Finally, $12-15$ years old are those whose thinking process can involve abstractions.

Piaget (in Fauziah, 2010: 90) perceives children as individuals who continually interact with the world around them. They grow by solving problems that are presented by their own environments. When they take actions to the problems, learning process occurs. This means the knowledge they obtain is not a gift with no effort. They obtain all they know as the result of self-construed active learning. They are eager to know everything new and therefore have high curiosity on everything they have never known, never met, and never thought before.

English popularity as a lingua franca waives the awareness of Indonesian people to learn. The decree of the Ministry of Education and Culture number 0487/4/1992, chapter VIII stipulates that English can be taught as an extra instruction if it is needed by the local community, and if the teacher of English is available. Though the decree addressed to English for kindergarten students is not stipulated, Fauziati (2010) perceives the significance of inserting English as a subject to kindergarten school is tangible.

However, teaching English for young learners, especially for kindergarten students is not easy to do (McKay, 2002). The overall learning process planned for them should be different from that for teaching adult. While Ellis(2003:30) offers some language strategies in teaching English for young learner. They are (1) it is broken into sense groups; (2) it is simplified but not unnatural; (3) it is more redundant than 'ordinary speech' and words and structures are naturally repeated or 'recycled' at regular intervals; (4) it is broken into 'short paragraph' segments to encourage or invite students to interrupt, comment and ask questions; (5) when new vocabulary or structure is taught, typical examples are given; and (6) the teacher gets regular feedback through questions - especially 'open questions' or 'two-step questions.

To make learning process successful and because of the student's limited capacity in processing languages in their mind, teachers should concider the use of (1) a mix of first language and English to converse with other children (Elliot, 2004); (2) using simple questions (Santosa, 2011); (3) joining in with familiar songs, rhymes, and poems (Wilcox in Fauziati, 2010); (4) using first language with peers who speak the same first language to clarify instructions; (5) responding to basic question words like who, what, where, and when; (6) communicating observations after teacher modeling (e.g., Our tower is 10 blocks high); (7) knowing and following directionality in text (York in Coulmas, 2005). The implementation of these seven points in teaching English for young learner is believed as the most effective way to be accepted by them because basically it is beyond what to teach if the learners are children. It is more about how to teach. By how, it means that the way we communicate, adjust our behavior, and so on which are even paramount to practice in order that teachinglearning process can run more successfully. 
As indispensable part of language teaching in an EFL (English as a Foreign Language) context, teacher talk brings instructional benefits for teachers (Kiasi and Hemmati, 2014: 95) for the organization of the classroom and the process of acquisition (Nunan, 1991: 89). Therefore, it is very significant for teachers to self-qualify on teacher-talk. The quality of teacher talk is determined by language background, previous language teaching experience, and formulated theoretical presuppositions about language learning and teaching (Stern, 1983: 35). In short, teachers are demanded to have linguistic skill and pedagogic skill in producing quality talk to their students. Specifically in teaching young learner, having one only of the two is a basic weakness. The skill includes not only spoken linguistic skill and pedagogic skill but also written one.

In conducting instructional process, written form is inherent to implement for it has its own strength to students' learning process. What is more, the importance of teacher talk in a writing course is not limited to the commonly discussed triadic structure of discourse, or a quantitative view of teacher talking time (TTT) but its pedagogical potential and appropriateness in relation to what is being taught are also of great importance (Kiasi and Hemmati, 2014: 90). On the other hand, Ellis (2003: 52) believes that teacher talk should coincide with a clear thematic focus and level adjustment that bring opportunities for students' self-regulated comments particularly in writing context.

Teacher talk has its own special style (Xiayo, 2006) which goals at communicating with students (Qican, 1999) and develops students' language capacity (Fauziati, 2010) and foreign language proficiency which advocates teachers to adopt the target language to promote their communication with learners (Richards, 2002). Studies of teacher talk commonly consist of the investigation of (1) language that teachers use in their language classrooms, and (2) language that they use in subject matter lessons. To respond to these two types, it is important that teachers consider list of classroom environment to the types of participants (Rodgers, 2000) and compare them with natural setting (Doughty, and Long, 2003) in order they can create and run the best teaching-learning atmosphere. Its significance is simply concluded from the fact where each classroom context bring with it different atmosphere which teachers should be sensitive with.

Further, to be specific on cognitive development, teaching English for young learners is specific other than that for adults where for young learners, Vygotsky (1978) affirmed that the probable cognitive development of a child is limited to a certain period of time called Zone of Proximal Development (ZDP). Hence, children need guidance. Accordingly, teachers need to modify systematically their speech while talking to young children. Coulmas (2005) proposes (1) the use of simple grammatical constructions; (2) The utterance is delivered slowly; (3) the articulation is spitted out very carefully; (4) the pauses of every utterance are clear; and (5) vocabulary is restricted: avoiding technical words and jargons to modify so. In this study, these five points are vital and therefore become the main tool in analyzing the teacher talk in teaching English for young learners. This is chosen because the five afore-explained points cover the whole points proposed by other experts and accordingly is reliable to be used to employ to describe teacher talk.

\section{Method}

This is a descriptive study which employed a group of kindergarten students and two teachers from Taman Kanak-Kanak (TK) Al-Azhar Syifa Budi, Surakarta. The learning process used joyful learning approach which perceives learning process as a process resurrecting students' happiness and enthusiasm. It can be seen from their chosen activities which prioritize playing and learning simultaneously by singing, dancing, and simple question-answer session. They 
learned greeting and naming fingers through singing where one teacher acted as the main instructor and another one as an assistant. To gain the resources validity, triangulation data involved observing the teaching-learning process, interviewing the two teachers and documenting the instructional process in video.

The rubric employed to manage the data is adopted from Coulmas (2005) and to simplify the form of analysis, all of these indicators are jotted down in number. For instance, if the teacher uses simple grammatical constructions: avoiding compound sentence, complex sentence, and compound- complex sentence, then the indicator will be symbolized by (1) which can be seen in coloumn symbol. Further, I also observe the expression made by the teacher and students to portray the real condition. It is meant to give descripion on how the teachers conducte teaching-learning process in the classroom. Table 1. depicts the Indicators of Linguistic Choices to teach Children adopted from Coulmas, 2005.

Table 1. The Indicators of Linguistic Choices to Teach Children adopted from Coulmas

\begin{tabular}{lc}
\hline \multicolumn{1}{c}{ The Indicators } & Symbol \\
\hline the use of simple grammatical constructions: avoiding compound, complex and & 1 \\
compound- complex sentence; & 2 \\
the utterance is delivered slowly & 3 \\
the articulation is spitted out very carefully & 4 \\
the pauses of every utterance are clear & 5 \\
vocabulary is restricted: avoiding technical word(s) and jargon(s). &
\end{tabular}

\section{Research Findings and Discussion}

\section{Findings}

The result of the analysis deals with the idea from the indicators described. It shows that (1) $100 \%$ of the utterances are in simple grammatical pattern by avoiding complex sentence to avoid students' misunderstanding in processing and interpreting the propositions given to them. 2) The utterance is $77 \%$ delivered slowly. It is so done to give students the space of time to process the sentence in their mind and to maintain their attention toward the saying. Some sentences uttered quite quickly are those which sound familiar to the students like greeting (selamat pagi) and it is acceptable to be delivered quicker than others. 3) The articulation is $66 \%$ clear. It is important to maintain the clarity of articulation because it is beyond children's capacity to understand jeopardizing articulation. 4) Vocabulary is restricted. The evidence why the vocabulary is $100 \%$ restricted and there is no any technical jargon is that the students could follow the instruction given and could also follow the flow of teaching-learning process well. 5) The pause's percentage is lower than $50 \%$. It is probably because of the very limited time they have. 6) such semantic content is rarely used because the material does not require any specific here and now even in form of instruction. In addition, the activity delivered through game and song proves that students, young learners, participation has been as what expected.

Table 2. shows the analysis of the conversation between teachers and students in the framework of Coulmas' theory of linguistic choices to children. 
Table 2. The Analysis Result of the Conversation

\begin{tabular}{|c|c|c|}
\hline UTTERANCES (“.....”) & EXPRESSION & SoI \\
\hline OK. Selamat pagi adik-adik... & $\begin{array}{l}\text { Energetic, motivating, kind, fast } \\
\text { saying }\end{array}$ & 1,4 \\
\hline Bagaimana kabarnya hari ini? & Friendly, smiling, & $1,2,3,4$ \\
\hline Alhamdulillah. Luarbiasa. Allahuakbar. Yess & Energetic, motivating & $1,2,3,4$ \\
\hline $\begin{array}{l}\text { /Adik-adik hari ini hari jum'at. Friday/ } \\
\text { / Kalian bahasa inggris diajar..../ } \\
\text { / Do you know my name? / } \\
\text { /siapa yang tahu namanya miss siapa di sini/ } \\
\text { /Miss.... Miss Ika.... My name is miss Ika and this } \\
\text { is my friend / }\end{array}$ & Questioning, & $1,2,4,5$, \\
\hline $\begin{array}{l}\text { /This week Miss Ika teaches you but next week miss } \\
\text { Zulfi will teach you/ } \\
\text { / Hari ini miss ika yang ngajar kalian. Minggu depan } \\
\text { kalian diajar sama miss. Zulfi/ } \\
\text { /Sebelum kita mulai ayo kita tepuk selamat pagi./ } \\
\text { / Bahasa inggrisnya Good morning. Siap ya.. / }\end{array}$ & Informing slowly, & \\
\hline $\begin{array}{l}\text { Selamat pagi. ((prok...prrok..prok.) Good morn- } \\
\text { ing...good morning...good morning... } \\
\text { n.b:The same pattern of analysis toward the next } \\
\text { utterance, i.e: good afternoon, good evening, good } \\
\text { night, good bye, and bye-bye. }\end{array}$ & $\begin{array}{l}\text { Imitating children's voice and } \\
\text { gestures but delivered quite fast } \\
\text { in speed }\end{array}$ & $1,3,4,5$ \\
\hline $\begin{array}{l}\text { /Iya sikat gigi dulu cuci kaki tangan/ } \\
\text { /Sikat gigi biar giginya enggak ber...lu...bang./terus } \\
\text { jangan lupa pamitan sama ayah ibu/ } \\
\text { /selamat malam ayah selamat malam bunda/ } \\
\text { /baca doa/siapa tahu doa mau bobok? / }\end{array}$ & Informing slowly & $1,2,3,4,5$ \\
\hline "Sekarang berdiri dulu ayo" & $\begin{array}{l}\text { Energetic, motivating, instruct- } \\
\text { ing }\end{array}$ & $1,2,4$ \\
\hline $\begin{array}{l}\text { /Goyang goyang atas bawah goyang goyang/ } \\
\text { /Goyang kanan goyang kiri berputarlah berputar/ } \\
\text { /Up and down and shake shake shake up and down } \\
\text { and shake shake shake/ } \\
\text { /Shake to the right and shake to the left turn around } \\
\text { and turn around/ } \\
\text { n.b:the same pattern of complete songs is analyzed } \\
\text { similarly with the lyric above. }\end{array}$ & $\begin{array}{l}\text { Singing happily together, } \\
\text { Manipulating children's move- } \\
\text { ment, } \\
\text { Imitating children's voice }\end{array}$ & $1,2,3,4,5$ \\
\hline
\end{tabular}

\section{The Descriptive Analysis:}

The number of representative utterances used: 9 (nine).

- Point 1: :9 times 9/9 X 100\%=100\%
- Point 2: 7 times

$7 / 9 \times 100 \%=77.7 \%$

- Point 3: 6 times $6 / 9$ X 100\% $=66.7 \%$

- Point 4: 3 times $3 / 9 \times 100 \%=33.33 \%$

- Point 5: 5 times 9/9 X 100\% $=100 \%$ 


\section{Discussion}

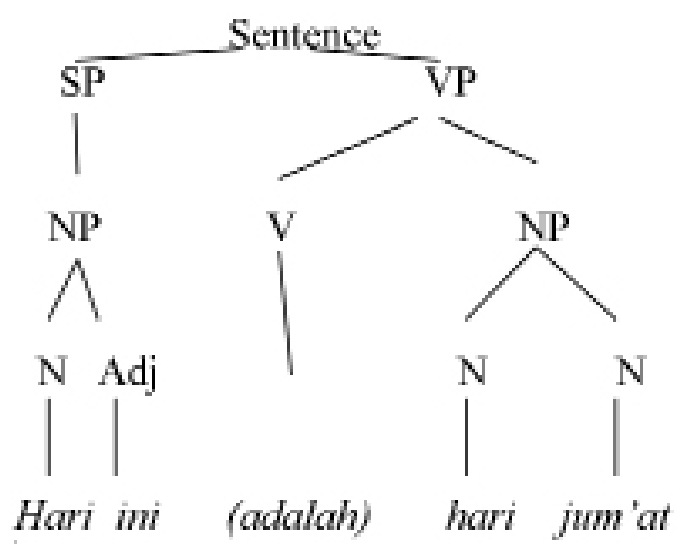

\section{The Utterance Used Simple Grammatical Pattern}

Children have limited capacity in producing and comprehending sentences. It is related to the development of their mind. In age three to seven, children are commonly able to produce and understand simple sentences. Therefore, the teachers adjusted the grammatical structure of their utterance into simple sentences. Here is given the example: Hari ini (adalah) hari Jum'at.

This sentencerepresents hundreds of other sentences the teachers uttered in the teachinglearning process. All the sentences have similar grammatical level unit of language which makes it valid to be represented by one sentence to generalize all utterances. The chosen-sentence consists of only one single sentence without any subordinate clause or embedded. In the conversation, it was found that 100 percent or all sentences which were uttered by the teachers and students are in form of simple sentence. This decision is practically correct because it is formulated to make students easy to understand. The style of the text is known with spoken-style. Coulmas (1992: 67) defines spoken style as a product of thought. Halliday (1985a) and McCharty (1991) state that spokenlanguage is used to act, think, and behaves directly in a social process and therefore is very suitable to be used to communicate to children. This suggests that the use of spoken style is more acceptable to the kindergarten students as their linguistic capacity is in the level of comprehending words, phrases and simple sentence only. This is strengthened by teacher $A$ that the most important point is how to make students understand, they need to modify utterances into simple sentence.

\section{The Utterance Was Delivered Slowly}

The reason why teachers should utter slowly is because children have slow response ability in processing every word coming into their mind. It is in line with Dardjowidjojo (2012: 267) that in parentsto-children conversation, parents often repeat their statements or questions to their children because children do not respond automatically. Taking this theory into account, it is significant for teachers to have language awareness by copying the way parents to communicate to their children. There is a space in time to respond which makes parents to slower their speech as Pan and Snow (1999: 233) found 3 year-old and up children will just respond $56.7 \%$ of what their parents said to them. Without this language awareness, students will find it hard to understand and follow instructional process. In terms of relevance, Owens (1996) state that children can only be 19\% relevant to the topic being discussed. Accordingly, teachers should realize that instructing just once to students is often unsuccessful. Teachers should be mentally ready to repeat teaching materials to students for two or three times in order that students 
can obtain and understand well. This study found that $77.7 \%$ of the utterance is delivered slowly. The slow utterances were done by both teacher and students. The teachers argued that they acted so to subserviently make students feel easier to comprehend. Accordingly, there must be an effort in terms of speech pace to kindergarten students to suit their linguistic capacity. This condition reminds teachers to concern with their speech pace in suitable and acceptable pace to their students in order that their speech is acceptable and students can understand more easily to what their teacher instructs.

\section{The Articulation Was Clear}

In order to support the intelligibility of the utterance to make students understand more easily, articulation holds a very important role. The slow utterance and clear articulation are hand-in-hand to adjust to students' capacity. From the study, $66.77 \%$ of the articulations sound clear. Not only were the words articulated clearly, but also was it delivered in clear intonation. Teachers imitated the way children get used to sounding: teachers sounded like a child. This is very beneficial for students because by listening such clear articulation and intonation, they will feel convenient to follow the learning process.

Particularly this phenomenon scrutinized by Yukichi Fukuzawa in Coulmas (2005: 32) who felt disgusted because he found that people were merely following the lead of the person speaking to him. In his research things he did not understand about the variable ways in which his interlocutors reacted to him are (1) in conversation people show inconsistency that he initially believed as the way to be subservient but it has nothing to do with it at all. People simply adjust ways of speaking to interlocutors based on social dimension, i.e; downward as an effort to be intelligible to the children, and upward as an effort to adjust the standard like talking to business colleagues; and (2) on the idea of respecting or identifying themselves in common membership of particular group, people also change to use the same accent to signal the solidarity. Therefore, the teachers supported its finding by arguing that down warding their standard utterance to the students (not to lower their status) aims at making them intelligible.

\section{The Vocabulary Was Restricted.}

The development of brain capacity occurs stage by stage. It is influenced by the experience of children themselves. When they see something new, they will ask their parents what the thing is called then remind it in their mind. They hear society talk and they save the dictions of the conversation in mind. However, their environment is still limited to where their social environment is. It makes children have limited vocabulary. Consequently, teachers should not produce any technical words which are never heard by the children before. Coulmas (2005: 29) states that it is important to understand that the limited vocabulary children have should make parents to also limit their vocabulary. The conversation shows that vocabulary is restricted. The evidence why the vocabulary was $100 \%$ restricted and there was no any technical jargon is that, from the teachers' view, the students could follow the instruction given and could also follow the flow of teaching-learning process well. In education setting, kindergarten students understand and follow instructional process well if the vocabulary in communication process is all common to hear by them.

\section{The Pause of Every Utterance Was Clear}

Pause is another technique which let students process the words they listen or they read in their mind to understand the words. As mentioned before, children need longer time to process what they hear and read in their mind because of their natural brain capacity. Accordingly, it is very important to do this technique to make intelligibility of the conversation by the students good. However, pause was less used by the teachers. Teacher 
sounded fairly quick in saying. The pause of from one sentence to other sentences was less than $50 \%$. Interview found it happened because teachers had so many things to say to the students. The teaching materials were a lot like singing a song about greeting, introducing finger, etc. Hence, influenced by the limited time, teachers looked so quick (for children) in explaining and communicating to their students.

Further, the expressions happening during teaching-learning process need to also be counted as teachers' effort in creating joyful learning. It is in line with Davies (2011) that teachers' utterances, interactions and expressions need to be explicit, appropriate, and relevant to the level of students in the classroom. The result of the observation shows that the expression mostly shown by the teachers varied from energetic, motivating, kind, fast saying, friendly, smiling, and happy expressions. It is suitable with children's characteristics and those expressions are expected to be able to stimulate students to be motivated, happy, impressed, and convenient in learning.

On the other hand, the activities were various. There was a game, singing songs, and dance. This was actually a very good strategy to make students feel excited and not bored. It is in line with Brendon (2013) that they have short attention span. So teachers should vary their techniques to break the boredom. They should give varied activities as handwriting, songs, games etc.. Many observations also show that children enjoy learning through playing. Young learners learn best when they learn through games. Let games be an essential part of your teaching.

\section{Conclusion}

From sociolinguistic perspective, teaching young learners is different from teaching adult because children's environments are still limited to parents, neighbors, and schools which influences students' capacity to be still limited to know vocabulary of what their parents, their teachers, and their friends utter. This kind of condition affects parents especially teachers a lot. In classroom context, teachers should be able to adjust their utterance while speaking to children by down-warding their linguistic choices. It is true that parents and other adults (in this case teacher) who interact with children (kindergarten students) systematically modify their speech while talking to them. Therefore, it is significant for teachers to adjust their talk on the extent of linguistic choices in teaching English for young learners to approach the flawless interaction during instructional process.

However, to support the quality of teaching learning process, teachers need to also do extra efforts to maintain students' attention and interest on the learning process. Accordingly, expressions of happiness, motivating, energetic, etc. are employed to attract students' attention because it is one of young learners' characteristic to demand the joyful learning environment. Another characteristic which is also important to consider is that children's very short attention span. Accordingly, teachers have to prepare variations of teaching strategy and shift the strategy every 10 to fifteen minutes like singing to games, games to dance, dance to storytelling, and others.

\section{References}

Ashworth, M. \& Wakefi eld, H.P. (2004). Teaching the world's children: ESL for ages three to seven. Toronto: Pippin Publishing.

Bolitho, Rod. (2006).'Teacher talk and learner talk." Journal of European Centre for Modern Languages, no. 2, vol. 2, $1-15$.

Brendon. (2013). "The Characteristics of Young Learners" (http://brendabrendon.blogspot. com/2012/12/characteristic-of-young-learners.html), accessed on $16^{\text {th }}$ November 2015 
California Department of Education. 2009. Preschool English Learners. California: Sacramento.

Chaudron, C. (2001). "Second Language Classroom Research: Evidence from the Modern Language." Modern Language Journal, no. 8 vol. 5.57 - 76.

Colley, Declan. 2014. "English Teachers, Are You Talking Too Much in Class?" (https://www. britishcouncil.org/voices-magazine/english-teachers-are-you-talking-too-much-class) accessed on 21 November 2016

Coulmas, F. 2005. Sociolinguistics: The Study of Speakers Choice. New York: Cambrige University Press.

Dardjowidjojo, Soenjono. 2012. Psikolinguistik: Pengantar Pemahaman Bahasa Manusia. Jakarta: Yayasan Pustaka Obor Indonesia.

Davies, Matthew J. 2011. “Increasing students' L2 usage: An analysis of teacher talk time and student talk time." Journal of English Language Teaching, no. 32, Vol. 2, 2 - 23.

Doughty, C. and Long, M.H. 2003. The Handbook of Second Language Acquisition. Oxford: Blackwell.

Dickinson, D. \& Tabors, P. (Eds.). 2001. Beginning literacy with language: Young children learning at home and at school. Baltimore, MD: Brookes Publishing.

Elliot, Joanne. 2004. "Six Group Activities for Teaching ESL Children." The Internet TESL Journal, no. 5, vol. 11, 2 - 18

Ellis, R. 2003. Task-based Language Teaching and Learning. Oxford: Oxford University Press.

Fauziati, E. 2010. Teaching English as a Foreign Language. Surakarta: Era Pustaka.

Gawi, Elsadig Mohamed Khalifa. 2012. "The Effects of Factor on Learning English: A Case Study of Learning English in Saudi Schools, Saudi Arabia." Canadian Centre of Science and Education, no. 5, Vol. 1, 127-139.

Halliday, M.A.K. 1985b. Spoken and Written Language. Victoria: Deakin University Press.

Kiasi, Mohammad Aghajanzadeh and Hemmati, Fatemeh. 2014. "The Importance of Teacher Talk in Teaching EFL Writing." Porta Linguarium, no. 22. Vol.1, 95 - 108.

Law, Sue Roulstone James, Rush, Roben, and Cleg, Judy. 2014. Investigating the Role of Language in Children's Early Educational Outcomes. UK Department of Education, Research Report.

McCarthy, M. 1991. Discourse Analysis for Language Teachers. Cambridge: Cambridge University Press.

McKay, S.L. 2002. Teaching English as an International Language: Implications for cultural materialsin the classroom. TESOL Journal, no. 9, vol. 4, 7-11.

Nunan, D. 1991. Language Teaching Methodology: A Textbook for Teachers. Cambridge: Cambridge University Press.

Owens Jr., Robert E. 1996. Language Development: An Introduction. Boston: Allyn and Bacon.

Pan, Barbara A. and Snow, E. Catherine. 1999. The Development of Conversational and Discourse Skill. London: Oxford University Press.

Piaget, J. 1972. The Language and Thought of the Child. Ohio: World Publishing Company. 
Qicen, Feng. 1999. "The Effect of Referential Questions on ESL Classroom Discourse." TESOL Quarterly, no. 20, vol. 2. 47 - 59.

Richards, J. 2002. The Context of Language Teaching. Cambridge: Cambridge University Press.

Rodgers, Ted. 2000. Strategies for Individualized Language Learning and Teaching. In Richard, Jack C. (Ed). 2000. Understanding Second and Foreign Language Learning Issues and Approaches. Rowley, Mass: Newbury House Inc. 251 - 273.

Snow, C.E. 1993. Billingualism \& Second Language Acquisition. Fort Worth: Harcourt Brace Jovanovich.

Stern, H. H. 1983. Fundamental Concepts of Language Teaching. Shanghai: Shanghai Foreign Language Education Press.

Taylor, I., \& Taylor, M. 1990. Psycholinguistics: Learning and Using Language. London: Newbury House.

Vygotsky, L. 1978. Mind in Society. New York: Harvard University Press.

Xiayo, Yan. 2006. "Teacher Talk and EFL in University Classroom.” Disertasi. Chongqing Normal University School of Language and Literature.

Yanfen, Liu \& Yuqin, Zao. 2010. "A Study of Teacher Talk in Interactions in English Classes." Chinese Journal of Applied Linguistics. no. 3, vol. 2, 76 - 87. 